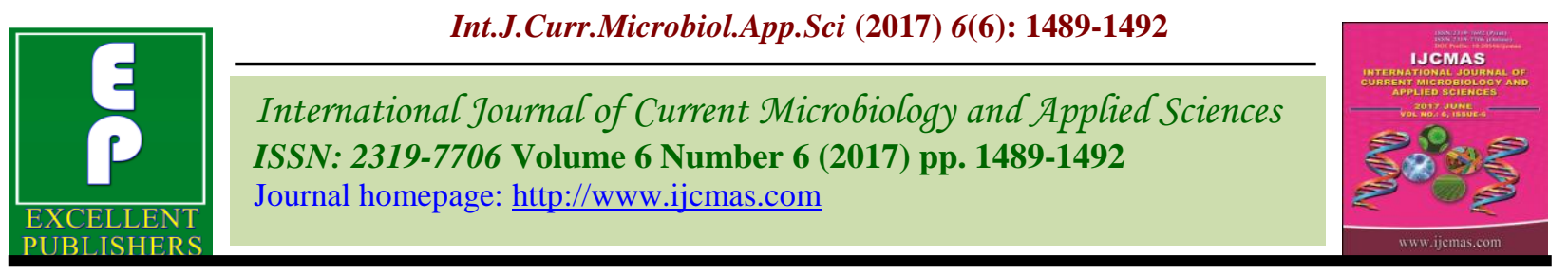

Original Research Article https://doi.org/10.20546/ijcmas.2017.606.175

\title{
Gross Morphological Studies on Sternum of Common Moorhen (Gallinula Chloropus)
}

\author{
Sajjad Ul Akbar Wani, Satish K. Pathak*, M.A. John, K. Ahmad, \\ F.A. Sheikh and S. Ishaque \\ Centre for Mountain Wildlife Sciences, SKUAST-Kashmir, India \\ *Corresponding author
}

\begin{tabular}{|c|c|}
\hline & A B S T R A C T \\
\hline \multicolumn{2}{|l|}{ Keywords } \\
\hline $\begin{array}{l}\text { Gross } \\
\text { morphological } \\
\text { studies, Sternum, } \\
\text { Moorhen. }\end{array}$ & \multirow{3}{*}{$\begin{array}{l}\text { The current study was designed with the aim to study the gross } \\
\text { morphological features of the sternum in four dead birds of Common } \\
\text { Moorhen. The sternum gives attachment to important flight muscles in } \\
\text { birds. The dorsal view of sternal body of Common Moorhen was roughly } \\
\text { pyramidal. The average length of sternal body was } 4.2 \text { centimetres. Sternal } \\
\text { keel was highly developed. The average height of sternum was } 1.1 \\
\text { centimetres, whereas the curvature length of keel was } 4.7 \text { centimetres. }\end{array}$} \\
\hline Article Info & \\
\hline $\begin{array}{l}\text { Accepted: } \\
\text { 21 May } 2017 \\
\text { Available Online: } \\
\text { 10 June } 2017\end{array}$ & \\
\hline
\end{tabular}

\section{Introduction}

The Common Moorhen, a member of the rail family, show worldwide distribution including Asia and Europe. The bird is commonly observed in the wetlands, lakes and reservoirs (Belton, 1994). Common Moorhen usually flies, with limited capability, in the night hours and is capable of performing local migration (Sirgrist, 2006). Anatomical study, of this bird, has been carried out on organs like liver and stomach (Jaseem et al., 2016; Ibrahim et al., 2016). However, to our knowledge little work has been reported on the skeletal system of this bird. The sternum gives attachment to important flight muscles in birds. The current study was therefore designed with the aim to study the gross morphological features of the sternum in this bird. Owing to the fact that there is a correlation between sternal morphometry and flight behaviour (Duzler $e t$ al., 2006), the study was also focussed to study the morphometry of the sternum in Common Moorhen.

\section{Materials and Methods}

For the current study four dead birds of Common Moorhen were collected during our studies (2013-2015) on aspects of ecology and conservation of Waterfowl of Chatlam Wetland, Pampore in South Kashmir. The carcasses of the birds were then kept in the sealed plastic jars for a period of three weeks for the natural maceration to occur. After reexamination of carcasses, it was observed that most of the muscular mass was digested by the anaerobic microorganisms. The sternal bone was separated and the left out residual 
mass on sternum was then removed by placing it in tap water mixed with 10-15\% washing soda $\left(\mathrm{Na}_{2} \mathrm{CO}_{3}\right)$ for one week (Duzler et al., 2006). Sternal morphometry was carried out (Duzler et al., 2006) and measurements on 1. Length of sternum; 2 . Curvature length of keel; 3. Height of keel, taken at its anterior most point, were recorded as the height of sternum. The mean values were then calculated and recorded.

\section{Results and Discussion}

The dorsal view of sternal body of Common Moorhen was roughly pyramidal with base cranially and caudally directed apex. The average length of sternal body was 4.2 centimetres.

Theoretically, with origin of caudolateral processes (Fig. 1) acting as demarcation point, the sternal body could be divided into two distinct parts; anterior and posterior. The former was quadrilateral and its anterior and posterior margins were demarcated by the origin of cranio and caudolateral processes, respectively.

The posterior part (Fig. 1), whose lateral borders formed the medial margins of the lateral notch (Fig. 1) on either side, was roughly triangular. Median groove was very prominent in the anterior half and became fainter in the posterior half.

The median groove at its cranial most end presented an elongated median pneumatic foramen (Fig. 1) the foramen was distinct in a way that it communicated with the ventral surface of the body. The craniolateral processes (Fig. 1) were short but moderately built, whereas caudolateral processes (Fig. 1) were long and thin. The latter enclosed an oval notch, one on either side. Caudolateral processes were terminated well behind the caudal end of sternal body. The latter, in its centre, presented rostrum in the form of a small pointed process (Fig. 2) the dorsal lip of the transverse groove showed a wellestablished central notch (Fig. 1).

Sternal keel (Fig. 2) was highly developed. The average height of sternum was 1.1 centimetres, whereas the curvature length of keel was 4.7 centimetres. The anterior end (Fig. 2) of the keel was concave and finished well behind the anterior end of sternal body. Towards the caudal aspect, the height of sternum showed a gradual decrease.

The shape of sternum in Pigeon hawk is rectangular, whereas it has been observed to be boat shaped in Red wattled lapwing (John et al., 2014a; John et al., 2015).

The average length of sternal body was 4.2 centimetres. The average sternal length in pigeon, crow and owl has been reported as $6.73,6.02$ and 4.69 centimetres, respectively (John et al., 2014b).

The posterior part, whose lateral borders formed the medial margins of the lateral notch on either side, was roughly triangular. The quadrilateral part on its lateral margins presented six costal facets for articulation with ribs (John et al., 2014a).

In blue rock pigeon the number of costal facets is five (Dewangan et al., 2014). Median groove was very prominent in the anterior half and became fainter in the posterior half.

The median groove has been observed to be shallow in the sternum of red wattled lapwing and pigeon (Dewangan et al., 2014; John et al., 2015) the median groove at its cranial most end presented an elongated median pneumatic foramen. The foramen was distinct in a way that it communicated with the ventral surface of the body. 
Fig.1 Photograph of sternum of adult moorhen showing (dorsal aspect) 1-caudolateral process 2costal facet 3-central notch 4-craniolateral process 5-oval notch 6-pneumatic foramen by arrows

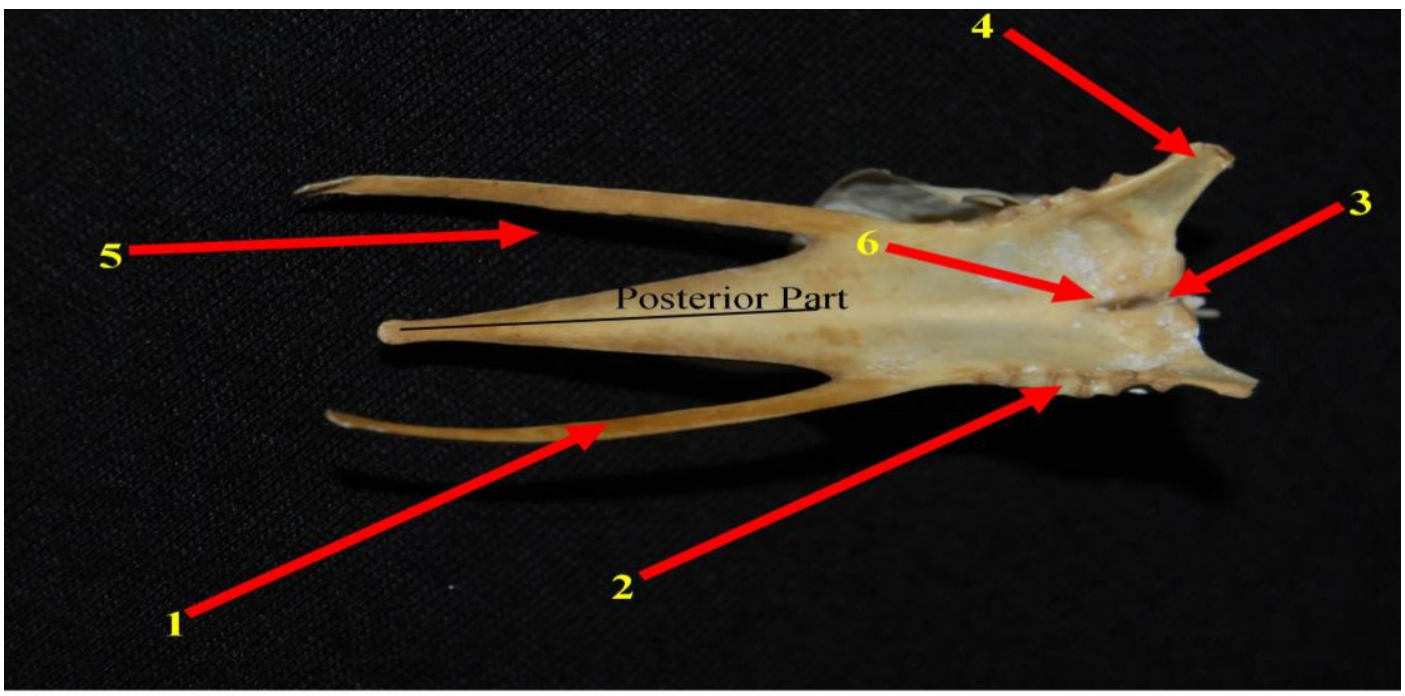

Fig.2 Photograph of sternum of adult moorhen showing (lateral aspect) 1-rostrum 2-anterior end by arrows

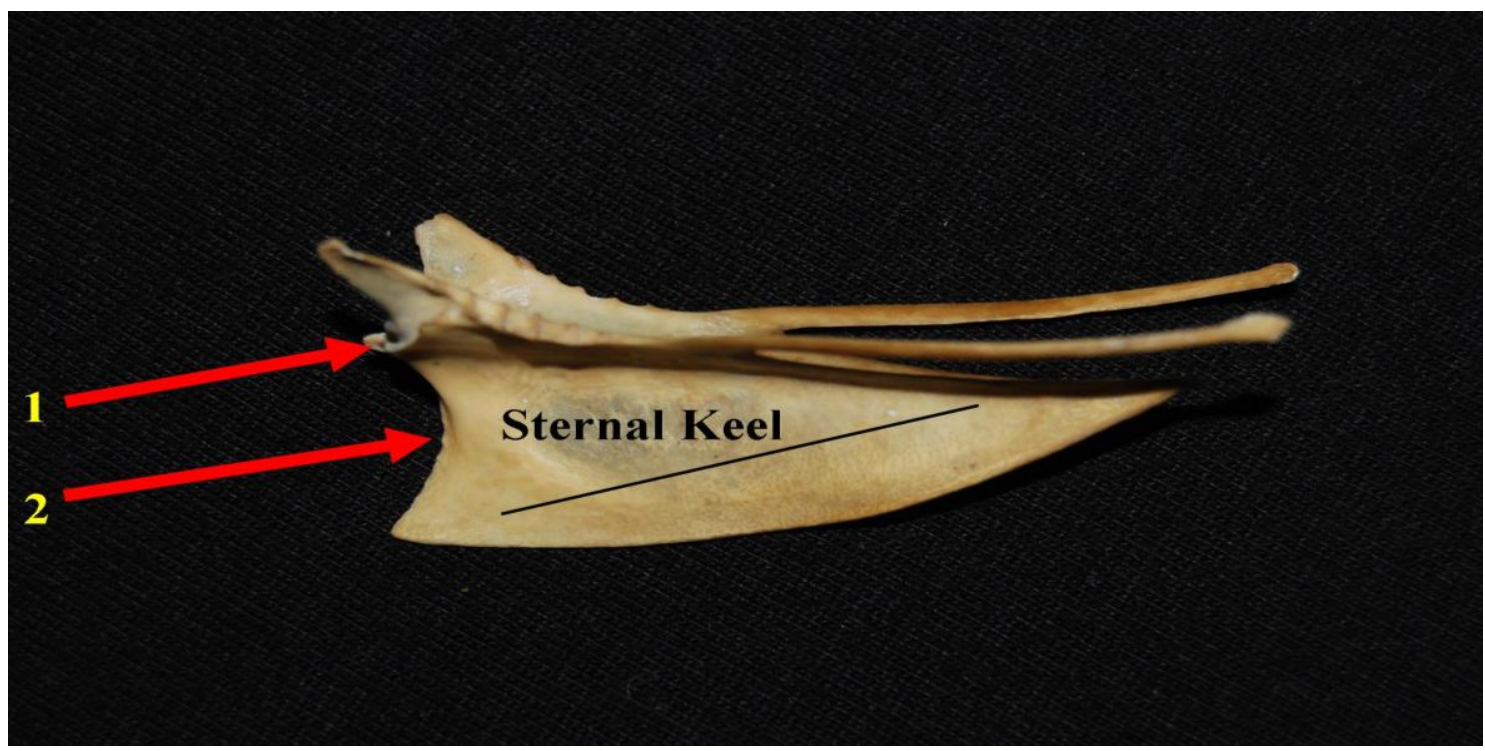

There is a single median pneumatic foramen in pigeon, whereas in crow and owl two additional foramen, one on either side, are present (John et al., 2014b). The craniolateral processes were short but moderately built, whereas caudolateral processes were long and thin. The latter enclosed an oval notch, one on either side. Caudolateral processes terminated well behind the caudal end of sternal body, in owl the craniolateral process is very well developed, while as in pigeon it is highly reduced. In pigeon hawk both caudolateral process and the oval notch are absent (John et al., 2014a).

The caudolateral processes were found to be two in pigeon unlike crow and owl, where it was single (John et al., 2014b). The anterior 
end of the body presented a transverse groove enclosed by a dorsal and a ventral lip (Predoi et al., 2009).

The latter, in its centre, presented rostrum in the form of a small pointed process in agreement with the reports of John et al., (2014a) in pigeon hawk. The dorsal lip of the transverse groove showed a well-established central notch. The central notch is also observed in owl and crow, whereas in pigeon it is replaced by a small bony mass (John et al., 2014b).

The anterior end of the keel was concave and finished well behind the anterior end of sternal body. Towards the caudal aspect, the height of sternum showed a gradual decrease. The height of the keel alone should not be considered as the index for flying abilities because in chicken the keel is deep, although it is a poor flier (Dyce et al., 2009).

\section{References}

Belton, W. 1994. Aves do Rio Grande do Sul, distribuição ebiologia. São Leopoldo, Unisinos. 584p.

Dewangan, B.K., Ingole, S.P., Chaurasia, D. and Singh, J. 2014. Morphometry of sternum of blue rock pigeon (Columba livia), Indian Vet. J., 91: 47-49.

Duzler, A., Ozgel, O. and Dursun, N. 2006. Morphometric analysis of the sternum in avian species. Turk. J. Vet. Ani. Sci., 30: 311-14.

Dyce, K.M., Sack, W.O. and Wensing, C.J.G. 2009. Textbook of Veterinary Anatomy, $3^{\text {rd }}$ Edn. W.B Saunders Co., Philadelphia, pp.791.
Jaseem, E.S., Hussein, A.J. and Sawad, Alla, A. 2016. Anatomical, histological and histochemical study of the proventriculus of common moorhen. Bas. J. Vet. Res., 14: 4.

John, M.A., Baba, M.A., Khan, M., Dar, F.A. and Sheikh, A.R. 2015. Gross morphological studies on sternum and shoulder girdle of red wattled lapwing (Vanellus indicus). Indian $J$. Vet. Anatomy, 27(2): 18-20

John, M.A., Mamde, C.S., Baba, O.K. and Rohankar, R.U. 2014a. Anatomical studies on the sternum of Pigeon hawk (Falco Coulambarius). Indian J. Poultry Sci., 49(2): 231-233

John, M.A., Sasan, J.S., Singh, A.D. and Choudry, A.R. 2014b. Morphometry of the sternum of pigeon (Columba livia), crow (Corvus splendens) and owl (Otus bakkamoena). Indian Vet. J., 91(03): 40-41.

Predoi, G., Belu, C., Dumitrescu, I., Georgescu, B., Seicaru, A., Rosu, P., Carmen, B. and Dumitrescu, F. 2009. Comparative researches regarding the sternum in Ostrich (Struthio camelus) and Nandu (Rhea Americana). Lucrari Sci. Med. Vet., 42: 342-346.

Sigrist, T. 2006. Aves do Brasil: umavisãoartística. SãoPaulo: Editora Avis Brasilis. 672p.

Waleed, J.A., Al-kelaby, Raad Shaalan Ibrahim and Ahmed Abdulla Hussein. 2016. Histomorphological study of the liver in local Moorhen birds (Gallinulachloropus) J. Vet. Med. Sci., 7: 2.

\section{How to cite this article:}

Sajjad Ul Akbar Wani, Satish K. Pathak, M.A. John, K. Ahmad, F.A. Sheikh and Ishaque, S. 2017. Gross Morphological Studies on Sternum of Common Moorhen (Gallinula Chloropus). Int.J.Curr.Microbiol.App.Sci. 6(6): 1489-1492. doi: https://doi.org/10.20546/ijcmas.2017.606.175 